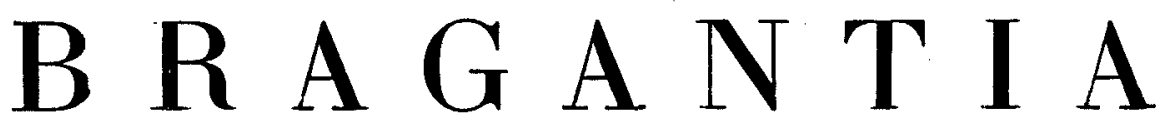

Boletim Científico do Instituto Agronômico do Estado de S. Paulo

Vol. 30

Campinas, maio de 1971

N. ${ }^{\circ} 10$

\title{
INCLUSÕES INTRACELULARES ASSOCIADAS À "ESPIGA BRANCA" DO TRIGO (1)
}

E. W. Kitajima ( $\left.{ }^{2}\right)$, V. R. Caetano $\left({ }^{3}\right)$ e A. S. Costa $\left({ }^{2}\right)$, engenheiros-agrônomos, Seção de Virologia Fitotécnica, Instituto

Agronômico

\section{SINOPSE}

Fragmentos da epiderme inferior de fôlhas de trigo com sintomas típicos da anomalia conhecida como "espiga branca", examinados ao microscópio convencional, mostraram a constante ocorrência de inclusões intracelulares, de dimensões avantajadas e de aspecto fibrilar e enovelado. Freqüentemente, células adjacentes àquelas que continham inclusões apresentavam formações aciculares, em seu interior.

Seções ultrafinas dessas fôlhas, examinadas ao microscópio electrônico, revelaram que tais inclusões eram de localização citoplasmática e formadas por uma massa de partículas filamentosas de 7-10 $\mathrm{m \mu}$ em diâmetro e de comprimento indeterminado, idênticas àquelas encontradas em preparações "leaf dip". Várias alterações celulares, como hipertrofia do nucléolo, degeneração dos cloroplastos e vesicularização do retículo endoplasmático, puderam também ser notadas. Ocasionalmente, formações cristalinas foram notadas na periferia e mesmo no interior do núcleo.

A semelhança das inclusões citoplasmáticas e das partículas que as compõem, com aquelas descritas, associadas à infecção do vírus da "hoja blanca" do arroz, e também o fato de o trigo desenvolver sintomas do tipo espiga branca quando inoculado experimentalmente com o vírus da "hoja blanca", parecem reforçar a sugestão de que a espiga branca do trigo teria etiologia virosa e que o agente causal seria do grupo do virus da "hoja blanca" do arroz.

A constante associação das inclusões celulares com a condição de espiga branca, em trigo, constitui mais um elemento para sua rápida diagnose.

(1) Trabalho apresentado na IV Reunião Anual da Sociedade Brasileira de Fitopatologia, realizada em Piracicaba, SP, de 15 a 17 de fevereiro de 1971 . Recebeu auxílio financeiro da FAPESP (C. Agron. 69/879), do CNPq (TC 12275) e do convênio CAPES/BID/BNDE. Recebido para publicação em 5 de março de 1971.

(2) Com bôlsa de suplementação do CNPq.

(3) Seção de Fitopatologia, IPEAS, Pelotas, RS. 


\section{1 - INTRODUÇ̃̃O}

Uma anomalia na cultura do trigo ( Triticum sativum L.), que se caracteriza entre outros sintomas pelo fato de as espigas se apresentarem sem grãos e de tonalidade amarelo-pálida a branca, tem sido constatada com relativa freqüência nos Estados de São Paulo, Paraná, Santa Catarina e Rio Grande do Sul. A condição tem sido referida como "espiga branca" (EB) e sua etiologia ainda não se acha perfeitamente estabelecida, embora haja suspeita de que possa ser uma moléstia causada por vírus (3).

O presente artigo relata os resultados de investigaçōes citológicas realizadias em tecidos foliares de trigo, afetados pela EB, ao nivel do microscópio convencional e do electrônico, procurando estabelecer a natureza da anomalia.

\section{2 - MATERIAL E MÉTODOS}

Fôlhas de plantas de trigo, de diferentes variedades e em diferentes estádios de desenvolvimento, exibindo sintomas típicos de EB, foram coletadas em plantações instaladas no IPEAS, Pelotas, RS, e nos terrenos do Centro Experimental de Campinas, do Instituto Agronômico, e da Fazenda Experimental Mato Dentro, do Instituto Biológico $\left({ }^{4}\right)$.

Fragmentos da epiderme inferior, retirados com auxílio de pinça de ponta fina, foram montados em água, diretamente ou após serem fixados por 5 minutos em aldeído glutárico a $3 \%$, e examinados ao microscópio convencional. Algumas amostras foram coradas com Trypan Blue a $0,5 \%$ (9), durante 5 minutos, antes de serem montadas em água.

Preparações "leaf dip", combinadas com contrastaçāo negativa (5), foram feitas de plantas afetadas pela EB e sadias, para verificar em microscópio electrônico a presença de partículas semelhantes a vírus.

Para histologia electrono-microscópica, pequenos pedaços de fôlhas, exibindo sintomas de EB ou normais, foram fixados em aldeído glutárico a $3 \%$ em tampão fosfato $0,05 \mathrm{M}, \mathrm{pH} 7,2$, durante 1-2 horas, a $4^{\circ} \mathrm{C}$. O material fixado foi desidratado em acetona e incluído em Epon (8). Os blocos foram secionados em ultra-

$\left(\begin{array}{l}4 \\ (\end{array}\right)$ Os autores agradecem ao eng "-agr." E. Issa, pelo livre acesso aos seus experimentos. 
micrótomo Porter-Blum, MT:1, com navalha de diamante. As seções foram contrastadas com acetato de uranila e citrato de chumbo, antes de serem examinadas em um microscópio electrônico Elmiskop I, da Siemens.

\section{3 - RESULTADOS}

Microscopia convencional - Uma das características marcantes da epiderme de fôlhas de plantas de trigo afetadas pela EB, sob o exame microscópico, foi a de muitas de suas células conterem inclusões de aspecto fibrilar e refringente, de dimensões avantajadas (estampa $1 A-C$ ). Estas inclusões tinham aspecto enovelado, formando figuras anelares e em oito, muitas vêzes circundancio completamente o núcleo. A fixação com aldeído glutárico não afetou a inclusão, mas uma acidificação do meio, como por exemplo pela introdução do ácido acético sob a lamínula, acarretou a imediata dissolução da inclusão. Por outro lado, o tratamento com Trypan Blue corou o núcleo, mas não a inclusão. Comumente pưđeram ser notadas formaçōes aciculares nas células adjacentes àquelas com inclusões (estampa 1-C). Tanto as inclusões como as agulhas não foram constatadas nas células-guardas dos estômatos. Em epiderme de fôlhas de plantas sadias, tais inclusões nunca puderam ser notadas.

Microscopia electrônica - Nas preparações "leaf dip" de plantas afetadas pela EB, notou-se consistentemente a ocorrência de partículas alongadas, flexíveis, de ca. $10 \mathrm{~m} \mu$ de diâmetro e de comprimento variável $(0,1 \mu$ a $2-3 \mu$ ) (estampa 1-D). Em algumas partículas puderam ser notadas indicações de um possivel canal axial. Tais partículas não foram encontradas em preparações análogas, feitas de plantas sadias.

O exame de seções ultrafinas, de tecido foliar de plantas com sintomas típicos de EB, mostrou em algumas delas a presença de enormes massas, de aspecto fibroso, no citoplasma de várias células, em pràticamente todos os tipos de tecidos da fôlha, exceto no vasos (estampas 2 e 3 ). Uma observação mais cuidadosa dessas massas citoplasmáticas mostrou que elas se compunham cie elementos fibritares, de 7-10 $\mathrm{m} \mu$ de diâmetro e comprimento indeterminável. Estas partículas filamentosas dispunham-se lado a lado, formando um feixe năo muito compacto (estampa 3-B). A massa de particulas fibrilares não apresentava membrana limitante, e usualmente jazia em uma zona do citoplasma, zona essa rica em ribosomas e pequenas vesículas. Suas dimensões gerais 
variavam de seção para seção, e podiam atingir $10 \mu$ ou mais em extensão. Algumas das células ficaram tomadas literalmente pela inclusão, aparecendo as suas componentes normais apertadas em meio à inclusão.

Bem menos freqüentemente certas células, contendo ou nâo as inclusões, tinham certas formações cristalinas, de dimensões reduzidas (ca. $0,5 \mu \times 0,5 \mu$ ), compostas de unidades de ca. $5 \mathrm{~m} \mu$ em diâmetro, dispostas em arranjo hexagonal. A maioria de tais cristais ocorreu em situação juxtanuclear, e em raros casos êles foram notados no interior nuclear (estampa 4).

Em várias amostras em que não se constatou a ocorrência da inclusão, observou-se no citoplasma o acúmulo de um material de baixa densidade electrônica, entremeado de elementos do retículo endoplasmático, e numerosos ribosomas (estampa 5). À baixa magnificação, êsse material, no conjunto, mostrou configurações similares às produzidas pelas inclusões fibrosas, sem todavia revelar, a magnificações maiores, nenhuma estrutura.

As células foliares, em plantas afetadas pela EB, mesmo quando não continham as inclusões, mostraram algumas alterações significativas. O nucléolo se mostrava ocasionalmente hipertrofiado (estampa 3 ). Os cloroplastos quase sempre apresentavam sinais evidentes de degeneração: sistema lamelar reduzido e desorganizado; estroma quase transparente, evidenciando bem os ribosomas; abundantes glóbulos osmiófilos; aparecimento de "supergranas"; projeçōes amebóides nas extremidades (estampas 2,5 ). Os mitocôndrios às vêzes apareciam hipertrofiados e em número reduzidio (estampa 5 ). O retículo endoplasmático, em certas células, achava-se reduzido a pequenas vesículas, mas em outras se mostrava extremamente-desenvolvido. O complexo de Golgi aparentemente ocorria em número menor que em células normais.

Certas seções mostravam a existência de células necrosadas, caracterizadas pelo fato de serem extremamente densas e contraídas.

Em tecidos de plantas sem sintomas (contrôle) não se constatou, em nenhum caso, a ocorrência de inclusōes fibrosas ou alterações celulares como as acima descritas. 


\section{4 - DISCUSSÃO}

As inclusões intracelulares de aspecto fibroso e enovelado, vistas ao microscópio convencional em fragmentos de epiderme, e as massas fibrosas citoplasmáticas, detectadas em seçōes ultrafinas de tecido foliar de plantas de trigo, afetadas pela EB, devem representar as mesmas estruturas. As mesmas posições relativas nas células em que são encontradas, bem como as formas e as dimensōes, contam-se para esta identificação. Por outro lado, as fibrilas componentes destas inclusōes são morfològicamente similares às partículas filamentosas encontradas nas preparações "leaf dip", e provàvelmente representam estas últimas in situ.

As massas fibrosas intracelulares, que constituem as inclusões, associadas à EB do trigo, são bastante similares àquelas encontradas em tecidos de plantas infetadas pelos vírus do amarelo da beterraba (4), tristeza dos citros $(6,10)$ e "hoja blanca" do arroz (Gálvez, comunicação pessoal). Em particular, a semelhança com as inclusões de vírus da "hoja blanca" do arroz é bastante grand'e, tanto pelo aspecto enovelado como pelas dimensōes e localização. Existe contudo uma diferença, que é o fato de as inclusões da "hoja blanca" ocorrerem, com certa freqüência, também no interior nuclear (Gálvez, comunicação pessoal) (estampa 6), o que aparentemente não ocorre no caso da EB.

Deve-se ressaltar também a semelhança das particulas filamentosas presentes em preparaçōes "leaf dip", obtidas de plantas afetadas pela EB, com aquelas dos vírus do amarelo da beterraba (2), tristeza ( 7 ) e "hoja blanca" do arroz (Shikata, comunicação pessoal), todos êles integrantes do grupo morfológico do vírus do amarelo da beterraba (1).

A natureza da EB do trigo ainđa não se acha perfeitamente esclarecida. Tôdas as tentativas de transmissão até agora feitas têm sido infrutíferas (3). Mesmo assim persiste a suspeita de que a anomalia tenha etiologia virosa, principalmente pelo fato de as plantas de trigo, experimentalmente infetadias pelo vírus da "hoja blanca" do arroz, exibirem sintomas semelhantes aos das plantas afetadas pela EB (Gálvez, comunicação pessoal). Esta suspeita parece estar bastante fortalecida com as presentes observações, em que se detectaram inclusões celulares caracterìsticamente associadas à anomalia, bem como a ocorrência de partículas filamentosas, similares a diversos outros virus, em preparações "leaf dip". Especialmente, a semelhança das inclusões associadas à EB com aquelas do vírus da "hoja blanca" é 
bastante acentuada. Assim, parece bastante provável ser a EB do trigo causada por um vírus, possivelmente do mesmo complexo ao qual pertence o virus da "hoja blanca" do arroz.

As alterações celulares observadas ao microscópio electrônico, particularmente a degeneração dos cloroplastos, explicam um dos sintomas externos das plantas afetadas, que é o amarelecimento intenso das fôlhas. Também o intenso metabolismo, que parece estar envolvido na síntese de enormes massas intracelulares, deve concorrer para o esgotamento rápido das células e a morte prenatura das plantas, ou na falta de frutificação normal.

O material amorfo encontrado em certas amostras talvez represente o mesmo material fibroso, dada sua morfologia geral localização, mas que teria sido degradado durante a fixação, que não teria sido suficientemente rápida para impedir a "dissolução" da inclusão. Uma mudança rápida do pH celular, durante o processo, talvez seja responsável pelo fenômeno.

A natureza das formações aciculares encontradas usualmente nas células adjacentes àquelas que continham inclusōes, na epiderme, ainda não se acha esclarecida. As formações cristalinas notadas ocasionalmente em seções ultrafinas talvez representem seções dessas agulhas, embora essa possibilidade pareça ser pouco provável, pelo fato de em nenhum caso terem sido observados cristais de forma alongada, sendo êles de reduzidas dimensões. Mas, a alternativa de que tais cristais representem um outro vírus que estivesse acidentalmente infetando a amostra, não deve ser desprezada.

A constante presença das inclusões enoveladas na epiderme e também em outros tecidos da lâmina foliar, em associação com a condição de espiga branca, em trigo, fàcilmente detectáveis mesmo ao microscópio convencional, constitui-se em mais um elemento adicional, para uma rápida e precisa diagnose da EB, além dos sintomas externos exibidos pela planta afetada.

INTRACELLULAR INCLUSIONS ASSOCIATED WITH WHITE SPIKE DISEASE OF WHEAT

\section{SUMMARY}

Light microscopic examination of epidermal strips from leaves of wheat (Triticum sativum L.) showing typical symptoms of the white spike (WS) disease, demonstrated the constant occurrence of huge, fibrous 
and whorled intracellular inclusions. Occasionally cells adjacent to those having inclusions contained needle-like formations. The whorled inclusions appeared in ultrathin section profiles as loose aggregates of thread-like elements, $7-10 \mathrm{~m} \mu$ in diameter and of indeterminable length, within the cytoplasm. They seem to represent filamentous particles found in leaf dip preparations from affected plants, in situ. Nucleolus hypertrophy, chloroplast degeneration and changes in endoplasmic reticulum were frequently noticed in affected tissues. Occasionally small crystalline inclusions were found nearby or within the nucleus.

The presence of these fibrous, whorled inclusions associated to WS condition, reinforces the suggested viral etiology, due to the similarity of these inclusions with virus aggregates found in tissues infected with several other viruses of the beet yellows virus group. Besides symptomatology, the particle and inclusion morphology of rice "hoja blanca" virus are very similar to WS of wheat, suggesting that both diseases are induced by viruses of the same complex.

The ease with which the inclusions are detected in epidermal strips, constitutes a quick and secure method to diagnose the WS disease.

\section{LITERATURA CITADA}

1. BRANDES, J. Identifizierung von gestreckten Pflanzenpathogenen Viren auf morfologischer Grundlage. Berlin-Dahlem, Biol. Bundesanstalt, 1964. (Mitt. 110)

2. _ — \& ZIMMER, K. Elektronenmikroskopische Untersuchungen über die virose Vergilbungskrankheit der Rübe (beet yellows). Phytopath. Z.24:211-215, 1955.

3. CAETANO, V. R.; COSTA, A. S. \& KITAJIMA, E. W. Espiga branca do trigo, uma possivel moléstia de vírus. Bragantia 29:XLI-XLIV, 1970.

4. ESAU, K.; CRONSHAW, J. \& HOEFFERT, L. L. Relation of beet yellows virus to the phloem and to movement in the sieve tube. J. Cell Biol. 32:71-87, 1967.

5. KITAJIMA, E. W. A rapid method to detect particles of some spherical viruses in fresh preparations. J. Electronmicroscopy (Tokyo) 14:119-121, 1965. .

6. — \& COSTA, A. S. Electron microscopy of the tristeza virus in citrus leaf tissues. In: Proc. Conf. Int. Org. Citrus Virol. 3ra, Rome 1966. 59-64.

7. ; SILVA, D. M.; OLIVEIRA, A. R.; MÚlleR, G. W. \& COSTA, A. S. Thread-like particles associated with tristeza disease of citrus. Nature 201:1011-1012, 1963. 
Vol. 30, N. 10

8. LUFT, J. H. Improvements in epoxy resin embedding methods. J. Biophys. Biochem. Cytol. 9:409-414, 1961.

9. MCWHORTER, F. P. Plant virus inclusions. Ann. Rev. Phytopathol. $3: 287-312,1965$.

10. PRICE, W. C. Flexous rods in phloem cells of lime plants infected with citrus tristeza virus. Virology 29:285-294, 1966.

11. REYNOLDS, E. S. The use of lead citrate at high pH as an electron opaque stain in electron microscopy. J. Cell Biol. 17:208-211, 1963.

12. WATSON, M. L. Staining of tissue sections for electron microscopy with heavy metals. J. Biophys. Biochem. Cytol. 4:475-478, 1958. 


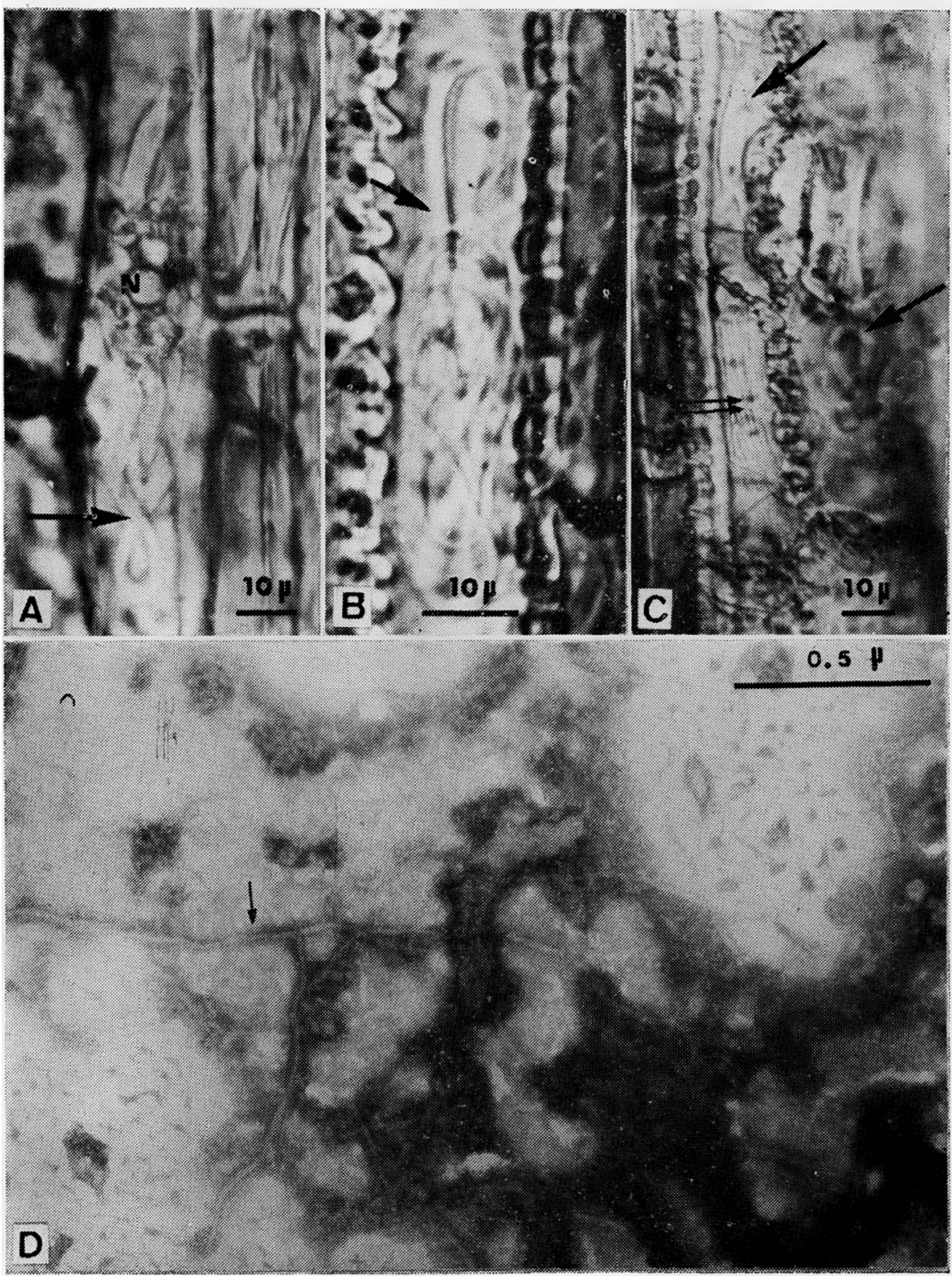

A-C Fotomicrografia de fragmentos de epiderme foliar de trigo afetado pela espiga branca (EB). Notem-so as inclusôes enoveladas (setas). Em C, uma das células adjacentes àquelas com inclusôes mostra formações aciculares (seta dupla). D- partículas filamentosas em preparação "leaf dip", contrastada negativamente, de trigo afetado pela EB. N- núcleo. 


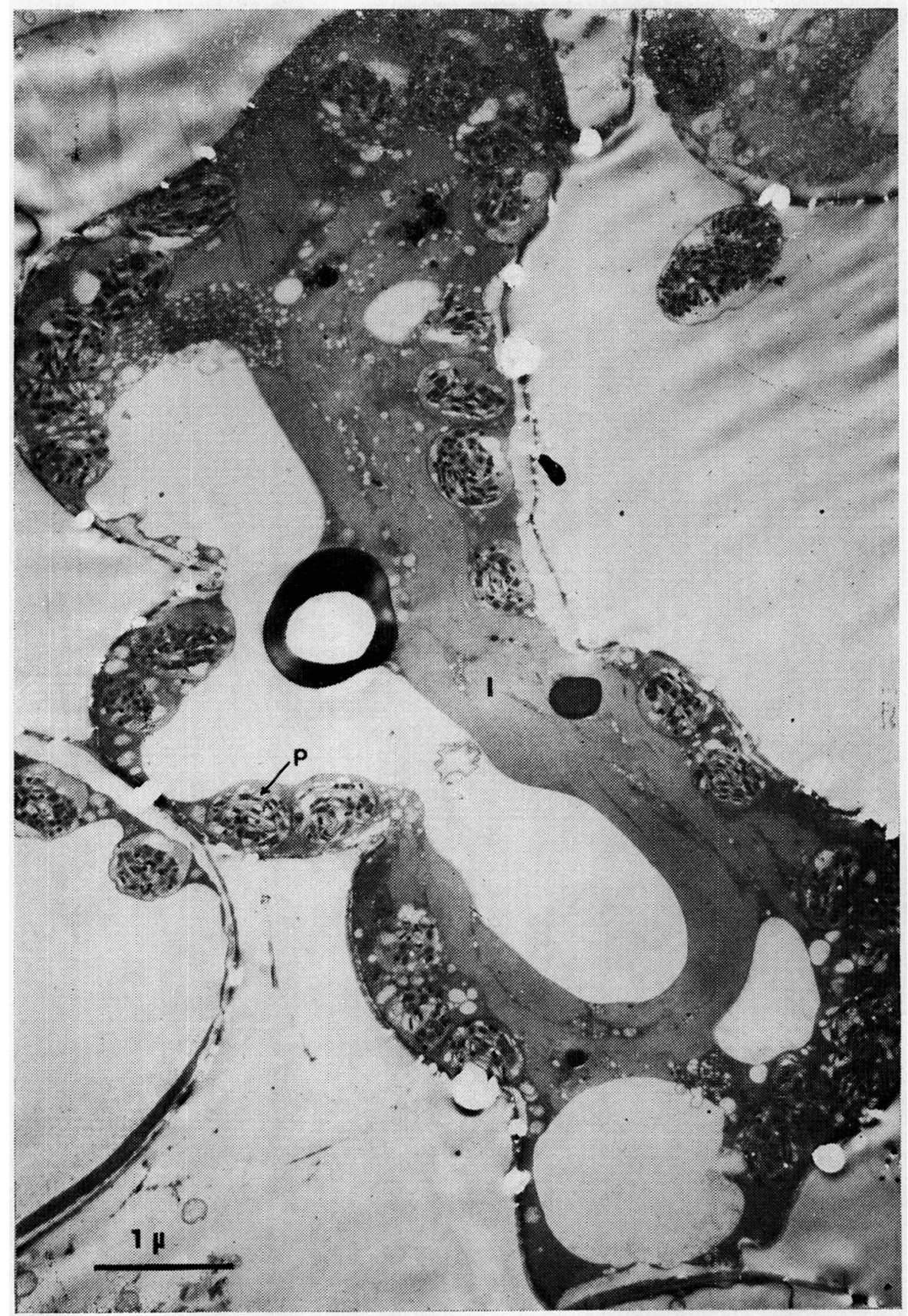

Seção ultrafina de uma célula do parênquima lacunoso de fôlha de trigo afetado pela EB. I- inclusão; P- cloroplasto. 


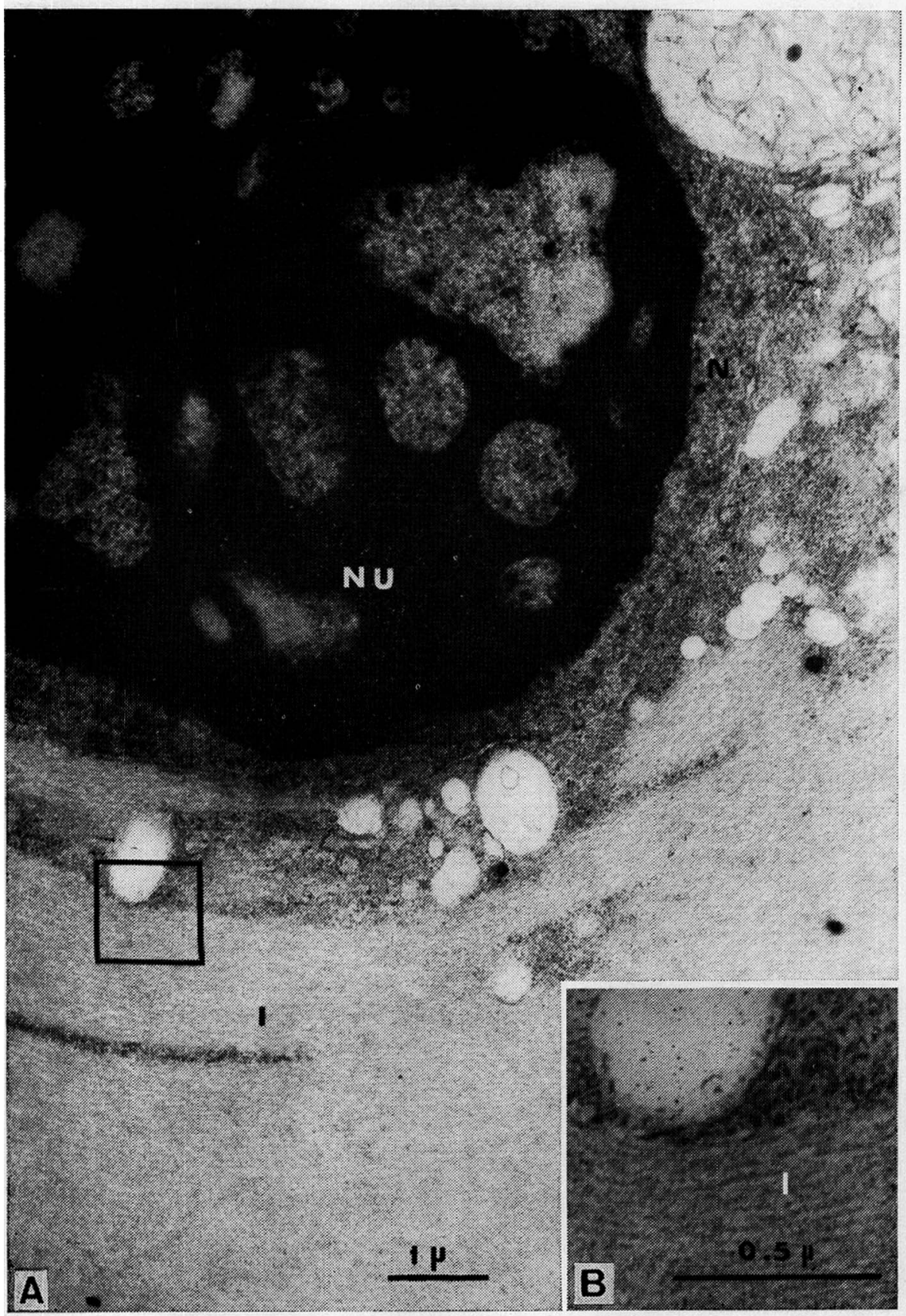

A- Parte de uma célula com inclusão (I) mostrando um nucléolo hipertrofiado (NU), e o aspecto fibrilar dos elementos componentes da jnclusão. Êste detalhe ć mais bem observado em $\mathbf{B}$, que representa uma ampliação da área assinalada em $\mathbf{A}$. N- núcleo. 


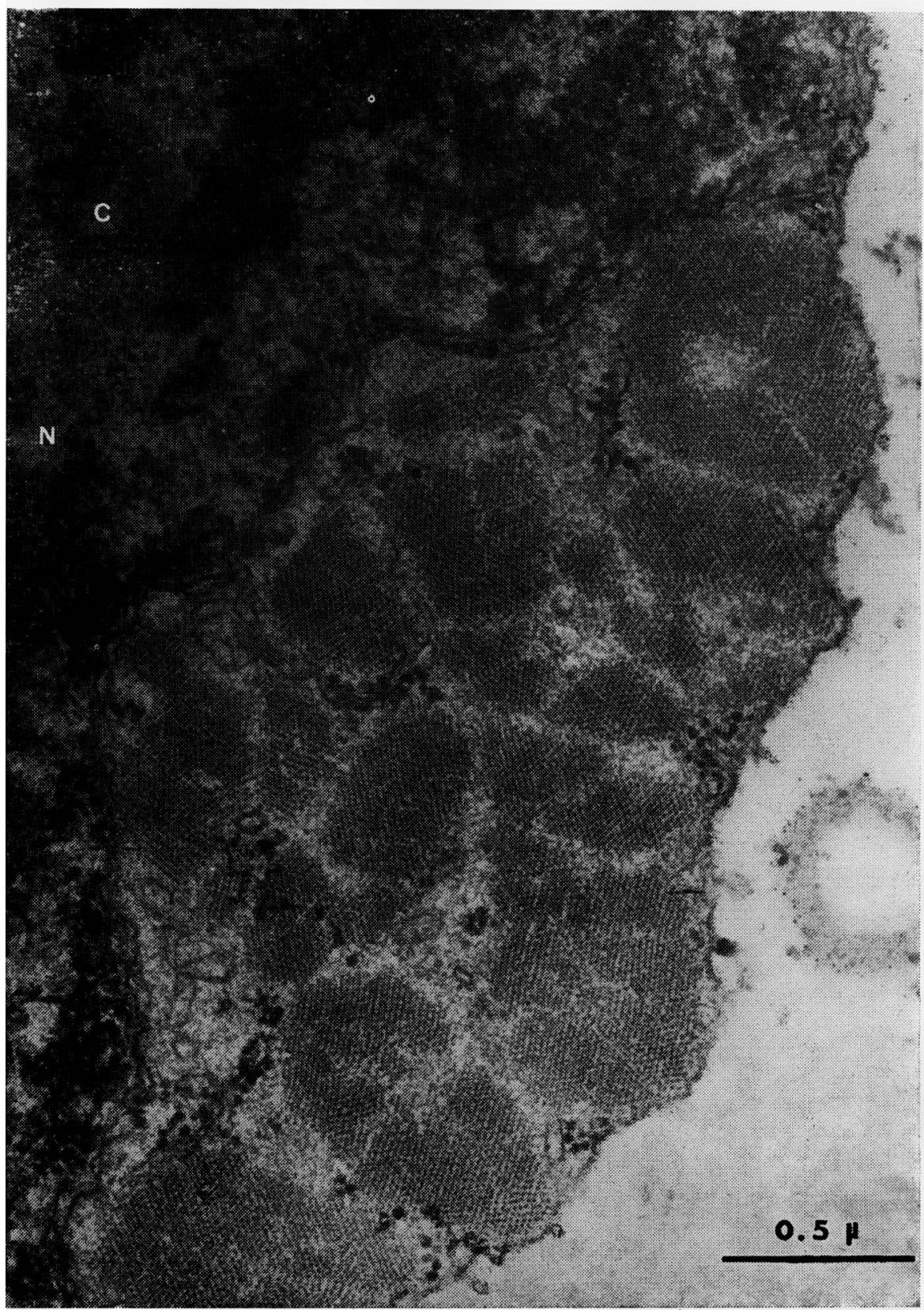

Formação cristalina (C) no citoplasma e no núcleo (N) de célula foliar de trigo afetado pela EB. 


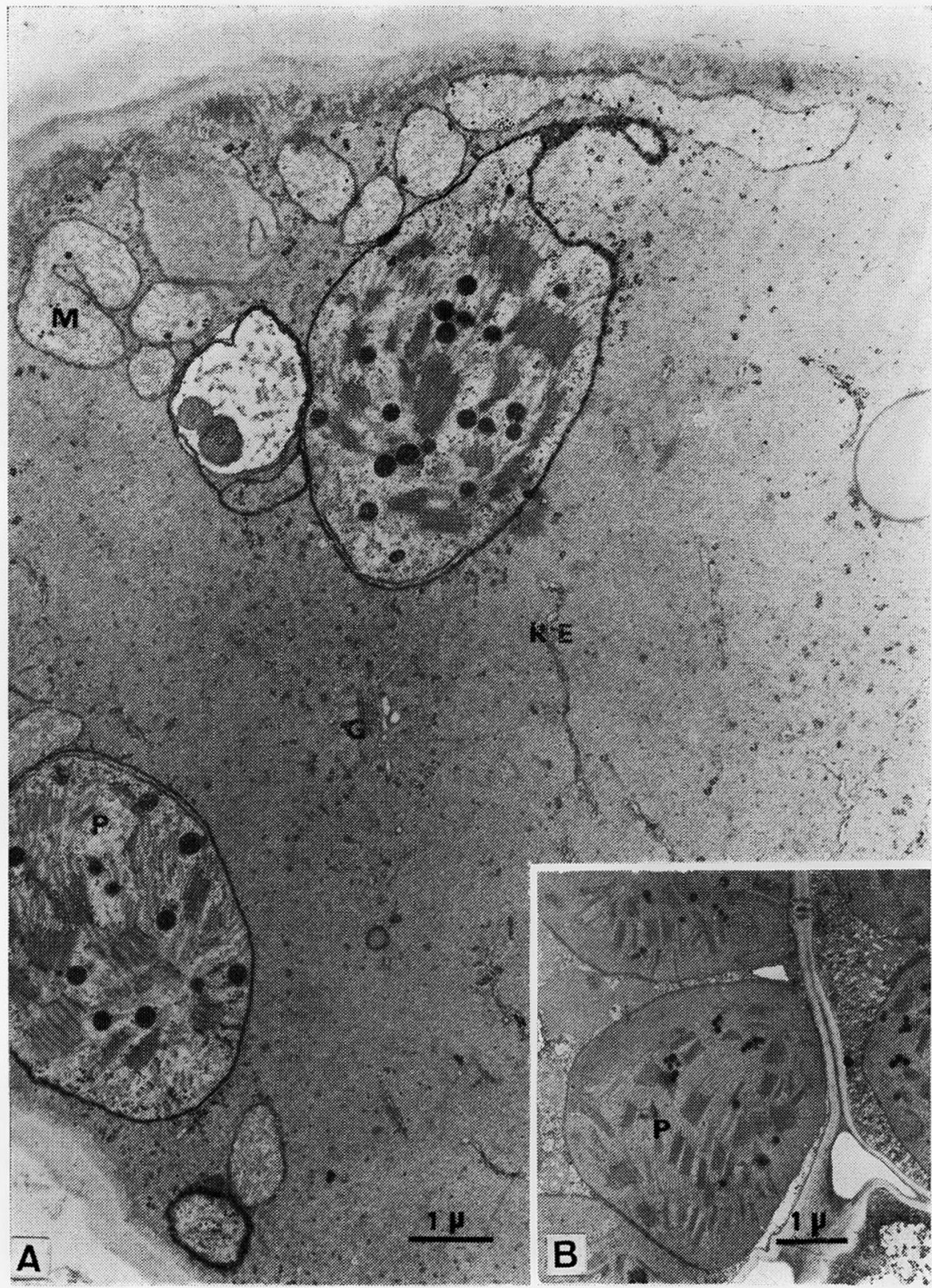

Parte de uma célula do parênquima lacunoso, em fôlha de trigo afetado pela EB, mostrando cloroplastos (P) em degeneração e a ocorrência de uma massa amorfa, entremeada de elementos do retículo endoplasmático (RE) e ribcsomas. Em B, cloroplasto de planta sadia. G- complexo đe Golgi; M- mitocônario. 


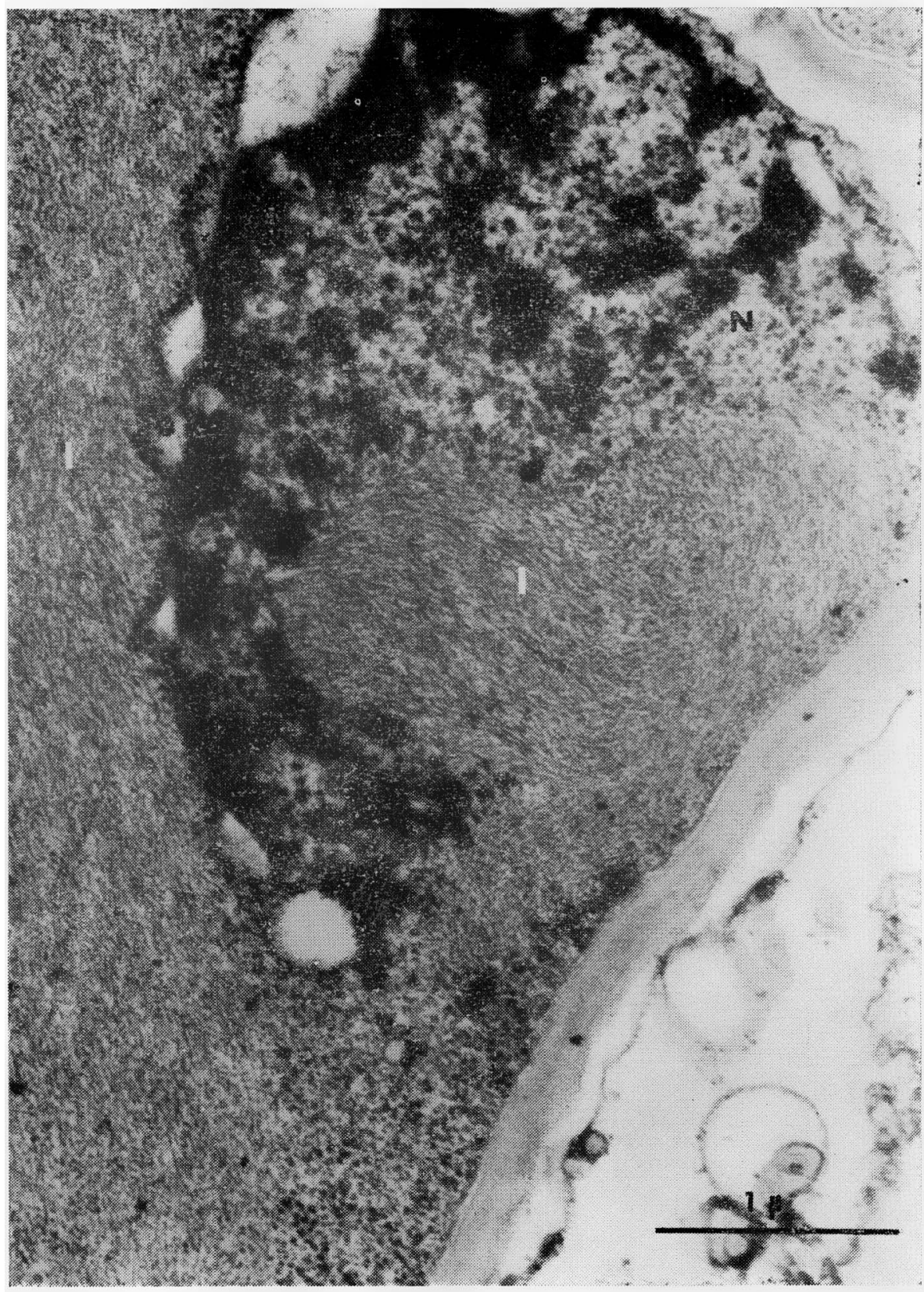

Célula foliar de arroz infetado pelo vírus da "hoja blanca". Inclusĩes de aspecto fibroso (I) ocorrem no citoplasma e no núcleo (N) ( $\mathrm{O}$ bloco, do material fixado e incluído em plástico, foi obtido por cortesia do Dr. Gálvez, da Colombia). 